\title{
Modelling height-diameter relationship for Pinus wallichiana trees for Lete and Kunjo of Mustang district
}

\author{
B. H. Wagle ${ }^{1}$ and R. P. Sharma ${ }^{2}$
}

\begin{abstract}
Quantification of height-diameter relationship helps in better understanding of stand dynamics. Height-diameter models can be used as necessary inputs to growth and yield models and growth simulation systems. The researchers developed height-diameter models with 364 Blue pine (Pinus wallichiana) tree data from Lete and Kunjo Village Development Committees (VDCs) of Mustang district. Eighteen non-linear models were calibrated, among which, Weibull model described the largest proportion of height variation $\left(\mathrm{R}_{\mathrm{adj}}^{2}=0.9362\right)$. Gunary and Chapman-Richards' models also appeared almost identical to Weibull model in terms of fit statistics and graphical appearance. The researchers recommend Weibull model for predicting total heights of Blue pine trees for the VDCs covered by the study.
\end{abstract}

Key words: Blue pine, height-diameter models, modelling, Mustang district

$\mathrm{T}^{\mathrm{T}}$ he measurements of individual tree height and diameter are essential component of forest inventories. Tree heights are used for estimating volume, site index, growth and yield, succession and carbon budget models (Peng, 2001). Although, theoretically, height can be measured on standing trees, practically, it is expensive, tedious and time consuming due to stand conditions and land configurations. Therefore, with many permanent or temporary sample plot systems, diameters for all trees, but height of only a few sample trees are measured. Alternatively, indirect estimation of tree heights can be made from diameter at breast height (dbh) which can be easily and accurately measured in relatively low cost. But for this, a site-and species-specific model describing a height-diameter relationship is necessary. Heightdiameter model can be developed using accurately measured heights and diameters from individual trees sampled from every stand within a forest. Height-diameter models are used to predict missing heights on the stands or permanent sample plots (Hasenauer and Monserud, 1997; NordLarsen, 2006; Nord-Larsen et al., 2009; Sharma et al., 2011). For height prediction purpose, several height-diameter models have been developed (Fang and Bailey, 1998; Huang et al., 2000; Huang et al., 1992; Moore et al., 1996; Newton and Amponsah, 2007; Sharma, 2009; Trincado et al., 2007; Zhang et al., 2004).
For a given species, height-diameter relationship differs from stand to stand due to variations in site quality and silvicultural treatments, and even within the same stand, due to variations in competition among individuals (Calama and Montero, 2004; Pretzsch, 2009; Vanclay, 1994). The climatic changes, changes of stand attributes (stand density), species provenance and combination of genetic potential, physiological and morphological response to environmental factors also affect height-diameter relationship. However, modelling height-diameter relationship by incorporating all those measures would be very complicated (Thornley, 1999; and literatures cited therein) would become costly. Heightdiameter relationship is highly site-dependent and, therefore, not constant over time even within the same stand (Curtis, 1967). A single height-diameter curve cannot be used for prediction of all possible height-diameter relationships that may exist within a forest.

The level of this variation can be significantly reduced through incorporation of individual stand dynamics (stand density, site index, dominant height, mean diameters, competition index) into height-diameter models (Adame et al., 2008; Crecente-Campo et al., 2010; Dorado et al., 2006; Newton and Amponsah, 2007; Schmidt et al., 2011; Sharma and Parton, 2007; Sharma and Zhang,

\footnotetext{
${ }^{1}$ Institute of Forestry, Tribhuvan University, Nepal. Email: bhwagle@gmail.com

${ }^{2}$ Department of Ecology and Natural Resource Management, Norwegian University of Life Sciences, Norway
} 
2004; Temesgen and Gadow, 2004). This approach, also known as comprehensive approach, may avoid a possibility of establishing stand-specific height-diameter relationship (Schmidt et al., 2011). However, getting all stand-based attributes would not be easy and cost effective, and therefore, are rarely considered for the general purpose models (Fang and Bailey, 1998; Huang et al., 2000; Leduc and Goelz, 2009; Lu and Zhang, 2011; Sharma, 2009).

Blue pine (Pinus wallichiana) constitutes one of the most important vegetation types in Mustang district (Chhetri et al., 2004). It occurs between $1800 \mathrm{~m}$ and $3600 \mathrm{~m}$ elevation, and very occasionally up to $4400 \mathrm{~m}$ (Jackson, 1994). A strong light demanding tree species in the youth onwards, it grows under moderate shade for many years. It is very sensitive to fire. While the saplings are frequently killed by fire, the large trees often succumb.

The species which constitutes a total stem volume of about 4.1 million $\mathrm{m}^{3}(1.1 \%)$ in Nepal (DFRS, 1999) is a prominent tree species for afforestation at higher elevations. Its growth rate is slower than that of Chir pine (Pinus ruxhurghii). However, its wood is comparatively much stronger. While the wood is used as a major timber source in Mid Hills, the bark is also used as roofing material (Kyastha, 1986). It offers a good economic share to communities in Mid Hill region. The Community Based Natural Forest and Tree Management in the Himalaya Project (ComForM Project) has started a long-term study on development of local communities and their interaction with Blue pine forests as the main livelihood resource in Mustang district (Meilby et al., 2006). There are only a few literatures reporting quantitative researches on Blue pine forest in Mustang (Wagle and Sharma, 2012; Wagle, 2007). Thus, the researchers intended to develop heightdiameter models for Blue pine forests in Lete and Kunjo VDCs of Mustang district by using height-diameter pairs as modelling variables. The height-diameter models will be used for prediction of heights, so that volume and yield estimation could be made easy. The heightdiameter models thus developed will serve as important tools for forest management in the district.

\section{Materials and methods}

\section{Study area}

The study was conducted in Blue pine forest of Lete and Kunjo VDCs of Mustang district, which are located between $28^{\circ} 24^{\prime} \mathrm{N}$ and $29^{\circ}$ $20^{\prime} \mathrm{N}$ Latitude, and between $83^{\circ} 30^{\prime} \mathrm{E}$ and $84^{\circ} 10^{\prime}$ E Longitude (Fig. 1). The study area lies within the working area of the Annapurna Conservation Area Project (ACAP). The elevation varies from $1372 \mathrm{~m}$ to $8167 \mathrm{~m}$, representing sub-tropical, temperate and alpine climate types. Vegetations cover about $4.05 \%$ of the district. Among eight vegetation types of the district, Blue pine is the most important one (Chhetri et al., 2004). Lete and Kunjo VDCs have also been included into the study area of the Community Based Natural Forest and Tree Management in the Himalaya Project (ComForM Project). For long term study purpose, this project has divided forests of Lete and Kunjo VDCs into 12 strata (Meilby et al., 2006). The present study focuses only on Blue pine dominated stands, irrespective of physical boundary of the strata.

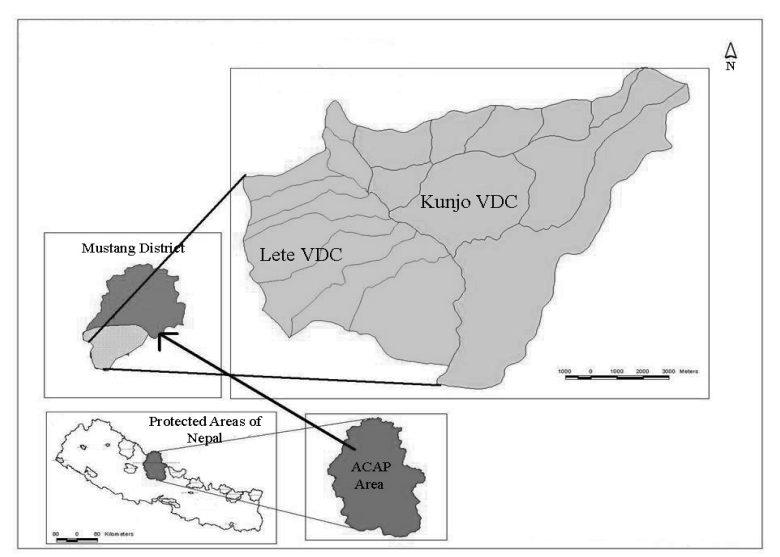

Fig. 1: Study area

\section{Data}

Some 27 to 35 Blue pine trees were selected from each diameter class (with $10 \mathrm{~cm}$ interval) from Lete and Kunjo VDCs, with representation of all possible stand densities and site qualities, and were numbered. The diameter at breast height $(\mathrm{dbh})$ and total height of each sample tree were measured in precisions of $0.1 \mathrm{~cm}$ and $0.1 \mathrm{~m}$, respectively. In this way, 184 trees from Lete and 180 trees from Kunjo were measured. Diseased, deformed, moribund, and top broken trees were discarded from sample. 
Data summary is presented in table 1.

Table 1: Data summary

\begin{tabular}{|c|c|c|c|c|c|}
\hline \multirow{2}{*}{$\begin{array}{l}\text { dbh class } \\
(\mathrm{cm})\end{array}$} & \multirow[t]{2}{*}{ Statistics } & \multicolumn{2}{|c|}{ Lete } & \multicolumn{2}{|c|}{ Kunjo } \\
\hline & & $\mathrm{dbh}(\mathrm{cm})$ & height (m) & $\mathrm{dbh}(\mathrm{cm})$ & height (m) \\
\hline \multirow[t]{4}{*}{$0-10$} & Mean & 5.7 & 4.8 & 7 & 4.7 \\
\hline & Min. & 2.8 & 2.9 & 3.53 & 2.25 \\
\hline & Max. & 9.8 & 8.75 & 9.8 & 7.9 \\
\hline & No. of obs. & 30 & 30 & 28 & 28 \\
\hline \multirow[t]{4}{*}{$10-20$} & Mean & 15.4 & 10.6 & 14.9 & 10.7 \\
\hline & Min. & 10.3 & 6.5 & 10.2 & 7 \\
\hline & Max. & 19.9 & 16.5 & 19 & 16.6 \\
\hline & No. of obs. & 35 & 35 & 29 & 29 \\
\hline \multirow[t]{4}{*}{$20-30$} & Mean & 24.8 & 15.9 & 25 & 16.7 \\
\hline & Min. & 21 & 10.8 & 20.3 & 10.8 \\
\hline & Max. & 29.9 & 22.65 & 29.9 & 23.4 \\
\hline & No. of obs. & 32 & 32 & 29 & 29 \\
\hline \multirow[t]{4}{*}{$30-40$} & Mean & 34.2 & 19.7 & 35.3 & 21.5 \\
\hline & Min. & 30.1 & 13.75 & 30.1 & 18 \\
\hline & Max. & 39.5 & 24.15 & 39.8 & 26.2 \\
\hline & No. of obs. & 29 & 29 & 34 & 34 \\
\hline \multirow[t]{4}{*}{$40-50$} & Mean & 44.9 & 25 & 45.2 & 26.1 \\
\hline & Min. & 40.3 & 21.4 & 40.8 & 19 \\
\hline & Max. & 49.8 & 30.2 & 49.7 & 31 \\
\hline & No. of obs. & 28 & 28 & 33 & 33 \\
\hline \multirow[t]{4}{*}{$>50$} & Mean & 63.3 & 28.5 & 56.2 & 28.3 \\
\hline & Min. & 50.7 & 23.9 & 50.7 & 20.5 \\
\hline & Max. & 87.2 & 35.05 & 69.5 & 32.4 \\
\hline & No. of obs. & 30 & 30 & 27 & 27 \\
\hline \multirow[t]{4}{*}{ Overall } & Mean & 30.7 & 17.1 & 30.9 & 18.2 \\
\hline & Min. & 2.8 & 2.9 & 3.53 & 2.25 \\
\hline & Max. & 87.2 & 35.05 & 69.5 & 32.4 \\
\hline & No. of obs. & 184 & 184 & 180 & 180 \\
\hline
\end{tabular}

\section{Modeling approach}

The graphs of observed height against dbh showed a clear non-linear relationship. Altogether, 18 different non-linear mathematical functions were tested (Table 2). Theoretically, height-diameter relationship increases monotonically in the beginning and then increases asymptotically in the later stage (Lei and Parresol, 2001 cited in Schmidt et al., 2011). The functions chosen in the study possess such properties. Many of them have previously been used by researchers for modelling tree or stands (Fang and Bailey, 1998; Huang et al., 2000; Huang et al., 1992; Leduc and Goelz, 2009; Newton and Amponsah, 2007; Sharma and
Parton, 2007; Sharma, 2006; Sharma, 2009; Sharma et al., 2011). Each function in Table 2 can be derived from the following general form:

$\left.H_{i}=1.3+f 9 D_{i}, b\right)+e_{i}$

where $H_{i}$ is total height of tree $i(\mathrm{~m}), D_{i}$ is dbh of tree $i(\mathrm{~cm}), \mathrm{b}$ is a vector of parameters to be estimated, and $e_{i}$ is a random error, and assumed to be independent and normally distributed with zero mean and a constant variance. A constant value 1.3 was added to avoid the prediction of $H_{i}$ shorter than $1.3 \mathrm{~m}$ when $D_{i}$ approaches zero. 
Table 2: Mathematical models considered

\begin{tabular}{|c|c|c|}
\hline Designation & Mathematical forms & References \\
\hline M1 & $H_{i}=1.3+b_{1}\left[1-\exp \left(-b_{2} D_{i}\right)\right]^{b_{3}}+\varepsilon_{i}$ & $\begin{array}{l}\text { Chapman-Richards [Richards (1959), } \\
\text { Chapman (1961)] cited in Sharma (2009) }\end{array}$ \\
\hline M2 & $H_{i}=1.3+\left[D_{i} /\left(b_{1}+b_{2} D_{i}\right)\right]+\varepsilon_{i}$ & Näslund (1936) \\
\hline M3 & $H_{i}=1.3+b_{1}\left[D_{i} /\left(b_{2}+D_{i}\right)\right]^{b_{3}}+\varepsilon_{i}$ & Näslund (1936) \\
\hline M4 & $H_{i}=1.3+b_{1}\left[D_{i} /\left(1+b_{1}+b_{2} D_{i}\right)\right]^{b_{3}}+\varepsilon_{i}$ & Näslund (1936) \\
\hline M5 & $H_{i}=1.3+b_{1}\left[1-\exp \left(-b_{2} D_{i}^{b_{3}}\right)\right]+\varepsilon_{i}$ & Weibull (1951) cited in Zeide (1993) \\
\hline M6 & $D_{i} /\left(b_{1}+b_{2} D_{i}+b_{3} \sqrt{D_{i}}\right)^{+\varepsilon_{i}}$ & Gunary (1970) cited in Ratkowsky (1990) \\
\hline M7 & $H_{i}=1.3+b_{1} \exp \left(-b_{2} D_{i}^{b_{3}}\right)+\varepsilon_{i}$ & This study \\
\hline M8 & $H_{i}=1.3+b_{1}\left[1-\exp \left(-b_{2} D_{i}\right)\right]+\varepsilon_{i}$ & $\begin{array}{l}\text { Meyer (1940) cited in Calama and Montero } \\
(2004)\end{array}$ \\
\hline M9 & $b_{2} \exp \left(b_{3} D_{i}\right)^{+\varepsilon_{i}}$ & $\begin{array}{l}\text { Huang and Titus (1993) cited in Leduc and } \\
\text { Goelz (2009) }\end{array}$ \\
\hline M10 & $H_{i}=1.3+\frac{b_{1} D_{i}^{2}}{\left(D_{i}+b_{2}\right)^{2}}+\varepsilon_{i}$ & Hossfeld (1822) cited in Sharma (2009) \\
\hline M11 & $H_{i}=1.3+\frac{D_{i}^{b_{1}}}{b_{2}+b_{3} D_{i}^{b_{1}}}+\varepsilon_{i}$ & Hossfeld (1822) cited in Sharma (2009) \\
\hline M12 & $H_{i}=1.3+b_{1} D_{i} / b_{2}+D_{i}+\varepsilon_{i}$ & This study \\
\hline M13 & $H_{i}=1.3+b_{1} D_{i} /\left(D_{i}+1\right)+b_{2} D_{i}+\varepsilon_{i}$ & $\begin{array}{l}\text { Bates and Watts (1980) cited in Calama and } \\
\text { Montero (2004) }\end{array}$ \\
\hline M14 & $H_{i}=1.3+\frac{D_{i}^{2}}{\left(b_{1}+b_{2} D_{i}+b_{3} D_{i}^{2}\right)^{2}}+\varepsilon_{i}$ & Curtis (1967) cited in Huang et al. (1992) \\
\hline M15 & $H_{i}=1.3+D_{i}^{2} /\left(b_{1}+b_{2} D_{i}\right)^{2}+\varepsilon_{i}$ & $\begin{array}{l}\text { Huang and Ti (1993)92) cited in Leduc and } \\
\text { Goelz (2009) }\end{array}$ \\
\hline M16 & $H_{i}=1.3+$ & $\begin{array}{l}\text { Ratkowsky and Reedy (1986) cited in Huang et } \\
\text { al. (1992) }\end{array}$ \\
\hline M17 & $H_{i}=1.3+b_{1} /\left[1+b_{2} \exp \left(-b 3 D_{i}\right)\right]^{+\varepsilon_{i}}$ & Huang et al. (2000) \\
\hline M18 & $H_{i}=1.3+b_{1} /\left[1+\exp \left(b_{2}-b_{3} D_{i}\right)\right]^{+\varepsilon_{i}}$ & Ratkowsky (1990) \\
\hline
\end{tabular}

Note: $H_{i}$ is total height of tree $i(\mathrm{~m}), D_{i}$ is dbh of tree $i(\mathrm{~cm}), b_{1}, b_{2}, b_{3}$ are parameters to be estimated, and $e_{i}$ is an error term.

Two locations, Lete and Kunjo, were coded with dummies ( 0 and 1$)$ to represent both by a single model. This was reasonable because no large difference was seen between the ranges of most of the height-diameter pairs for two locations

(Fig. 2). Smaller difference was due to site-specific productivity difference, and it could be described by dummy variables used as site-specific variables. For best performance, we assumed a parameter 
$\left(b_{1}\right)$ of each model (Table 2) as a linear function of location variable (site-specific variable) as below: $b_{i}=c_{i}+c_{2}$ location

where $c_{1}, c_{2}=$ parameters to be estimated, and location variable comprises dummies ( 0 for Lete, 1 for Kunjo).The parameters related to location variable (i.e. site-specific parameters) and other parameters in the models were all simultaneously estimated (Huang et al., 2000; Wagle and Sharma, 2012).

\section{Parameter estimation and model evaluation}

The parameters of the models (Table 2) were estimated with non-linear least square regression using PROC MODEL in SAS (SAS Institute Inc., 2008). The fitted models were evaluated on the basis of various criteria such as (1) significance of parameter estimates at $1 \%$ level or even less (i.e., p d” 0.05), (2) logical and biological consistency of the estimated parameters, (3) histograms and probability plots of residuals, (4) graph of residuals against fitted values, (5) root mean squared error (RMSE) and adjusted coefficient of determination $\left(R_{a d j}^{2}\right)$ (Montgomery et al., 2001), (6) Akaike information criterion (AIC): it is one of the most reliable criterion to compare the fitted models with differing parameter numbers. Smaller the AIC value, better would be the model (Burnham and Anderson, 2002), and (7) model curves overlaid on observed data. The examination of graphs helps understanding about whether models are based on theoretical basis and biological logics (Alder, 1995; Fang and Bailey, 1998). The curves generated with models were checked with respect to their biological realism.
Like many others (Soares et al., 1995; Vanclay and Skovsgaard, 1997), the researchers also believe that validation is an important part of modelling, because validation increases the credibility and confidence about the developed models. However, the researchers did not perform that as they lacked independent data. Also, the researchers did not consider validation by splitting data as they had too small data set. The validation by data splitting does not provide any better information as compared to that obtained directly from the model fitted to the entire data set (Kozak and Kozak, 2003). Nevertheless, validating model with independent data is the best option, but it certainly becomes costly (Vanclay, 1994).

\section{Results and discussion}

The models (Table 2) were fitted to the data, and parameter estimates and fit statistics are presented in table 3 . The parameter estimates of each model including parameters related to location variable (site-specific variable) were all significant at $1 \%$ level or even less ( $\mathrm{d}$ " 0.01), and the estimated parameter values and signs are logical. In general, all models fitted to the data well with almost identical fit statistics. Among all, M5 showed the best fits (smallest RMSE and AIC and largest $\mathrm{R}_{\text {adj }}^{2}$ ) followed by M6, M1, M16, M3 and so on, and M18 and M17 showed the poorest fits (largest RMSE and AIC, and smallest $\mathrm{R}_{\text {adj }}^{2}$ ) followed by M9, M12 and so on. 
Table 3: Parameter estimates and fit statistics

\begin{tabular}{|c|c|c|c|c|c|c|c|}
\hline \multirow[b]{2}{*}{ Models designation } & \multicolumn{4}{|c|}{ Parameter estimates } & \multicolumn{3}{|c|}{ Fit statistics } \\
\hline & $\mathbf{c}_{1}$ & $\mathbf{c}_{2}$ & $\mathbf{b}_{2}$ & $\mathbf{b}_{3}$ & RMSE & $\mathbf{R}^{2}$ adj & AIC \\
\hline M1 & 35.4895 & 1.6880 & 0.0277 & 1.2747 & 2.1458 & 0.9362 & 560.81 \\
\hline M2 & 2.4474 & -0.1629 & 0.0732 & 1.5220 & 2.1574 & 0.9355 & 563.77 \\
\hline M3 & 52.3627 & 2.6925 & 32.7124 & 1.5150 & 2.1542 & 0.9357 & 563.67 \\
\hline M4 & 1.4470 & -0.1628 & 0.0732 & 1.5217 & 2.1604 & 0.9353 & 565.77 \\
\hline M5 & 34.1267 & 1.5874 & 0.0120 & 1.1934 & 2.1449 & 0.9362 & 560.51 \\
\hline M6 & 2.3949 & -0.0866 & 0.0408 & -0.3402 & 2.1451 & 0.9362 & 560.58 \\
\hline M7 & 100.6136 & 5.4975 & 7.6948 & -0.4318 & 2.1701 & 0.9347 & 569.01 \\
\hline M8 & 43.8929 & 2.4250 & 0.0161 & & 2.1977 & 0.9330 & 577.22 \\
\hline M9 & 28.6053 & 0.9177 & 8.3887 & -0.0835 & 2.2980 & 0.9268 & 610.73 \\
\hline M10 & 47.3770 & 2.3077 & 19.5773 & & 2.1679 & 0.9348 & 567.29 \\
\hline M11 & 3.1471 & -0.2649 & 1.3114 & 0.0220 & 2.1546 & 0.9356 & 563.82 \\
\hline M12 & 72.6786 & 4.2468 & 100.1679 & & 2.2236 & 0.9314 & 586.76 \\
\hline M13 & 0.7255 & 0.0424 & -0.9900 & & 2.2206 & 0.9316 & 584.76 \\
\hline M14 & 7.0652 & -2.0615 & 0.9314 & 0.0189 & 2.1839 & 0.9339 & 573.65 \\
\hline M15 & 2.9004 & -0.1868 & 0.1437 & & 2.1734 & 0.9345 & 569.12 \\
\hline M16 & 44.7041 & 2.2174 & 0.0074 & 1.3051 & 2.1496 & 0.9359 & 562.10 \\
\hline M17 & 28.6010 & 0.9175 & 8.3902 & 0.0835 & 2.2980 & 0.9268 & 610.73 \\
\hline M18 & 28.6120 & 0.9179 & 2.1266 & 0.0834 & 2.2980 & 0.9268 & 610.73 \\
\hline
\end{tabular}

I he researchers also examined each model's residual graphs (graphs of individual residuals and mean residuals calculated by height and dbh classes) and model curves overlaid on the observed data. Here, due to brevity of space, we present the graphs of the first three best models (M5, M6 and M1) and one poorest model (M18) (Fig. 2,3). Except models M9, M17 and M18, residual graphs of all other models showed no systematic bias across the observed dbh and height classes, and their fitted curves showed biologically logical properties. Most of the individual residuals of each model were found within $95 \%$ confidence limit, and histogram of residuals looked like a bell shape. This indicates there is no sign of heteroscedasticity attributed to the models. The first three best models (M5, M6 and M1) seem to be very identical in terms of residual graphs also (Fig. 2). The logistic type of models (M9, M17 and M18) showed larger over-prediction for very small trees and under-prediction for very larger trees. The logistic types of functions seem to be less appropriate for more accurate height-diameter models (Sharma, 2009).

The height-diameter relationship increases monotonically in the beginning, reaches to inflection point and increases asymptotically in the later stage (Lei and Parresol, 2001 cited in Schmidt et al, 2011). In the later stage, diameter needs to grow faster in order to firmly withstand whole stature of tree against the external force such as wind blow (Cato et al, 2006; Khanna and Chaturbedi, 1994). Height position of curve after about $20 \mathrm{~cm} \mathrm{dbh}$ for Kunjo (location =2) might be due to faster growth of both diameter and height as compared to those in Lete (location =1) (Fig. 3). It also suggests that height-diameter relationship may be site-specific, and therefore a single curve cannot be used for the prediction of all possible height-diameter relationships for larger forest area. But, this level of variations could be reduced by incorporating the individual stand dynamics (stand density, site index, dominant height, mean 
M1
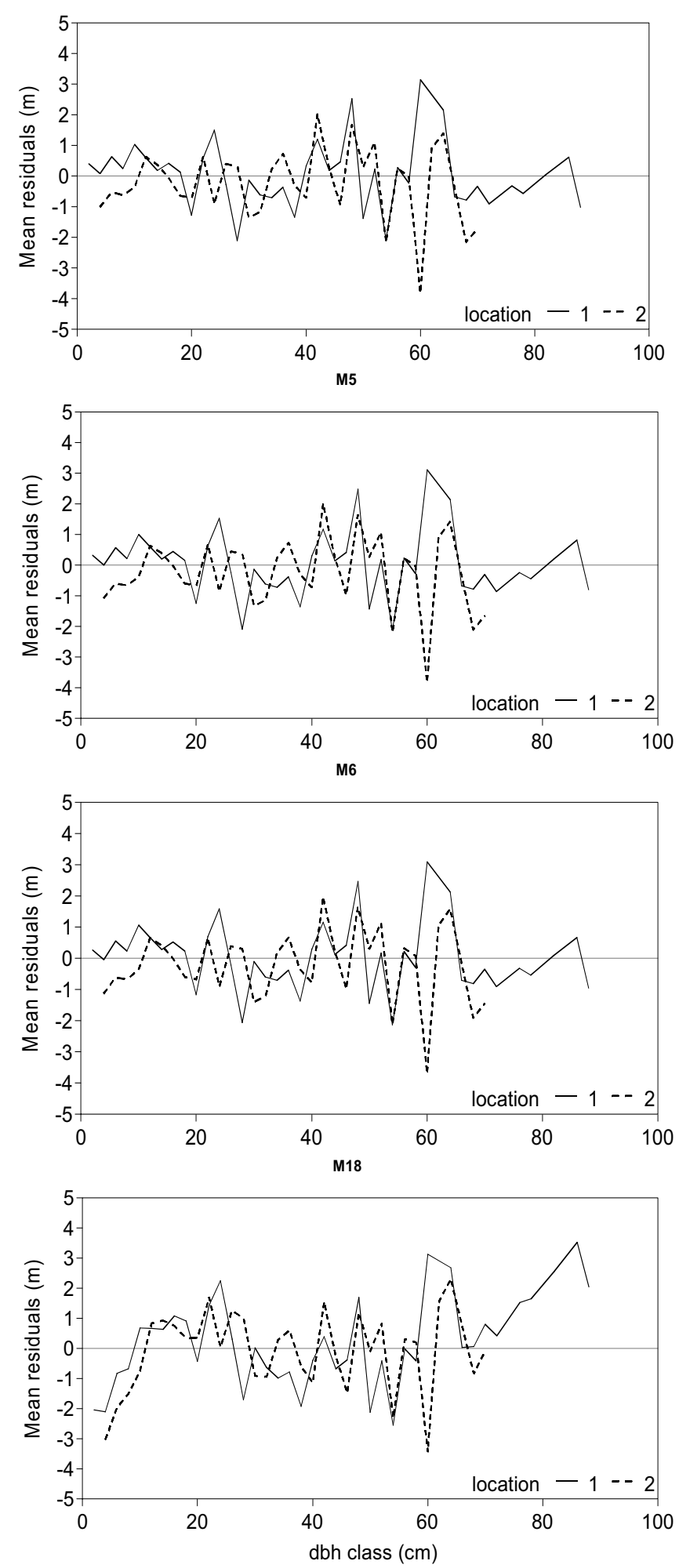

M1
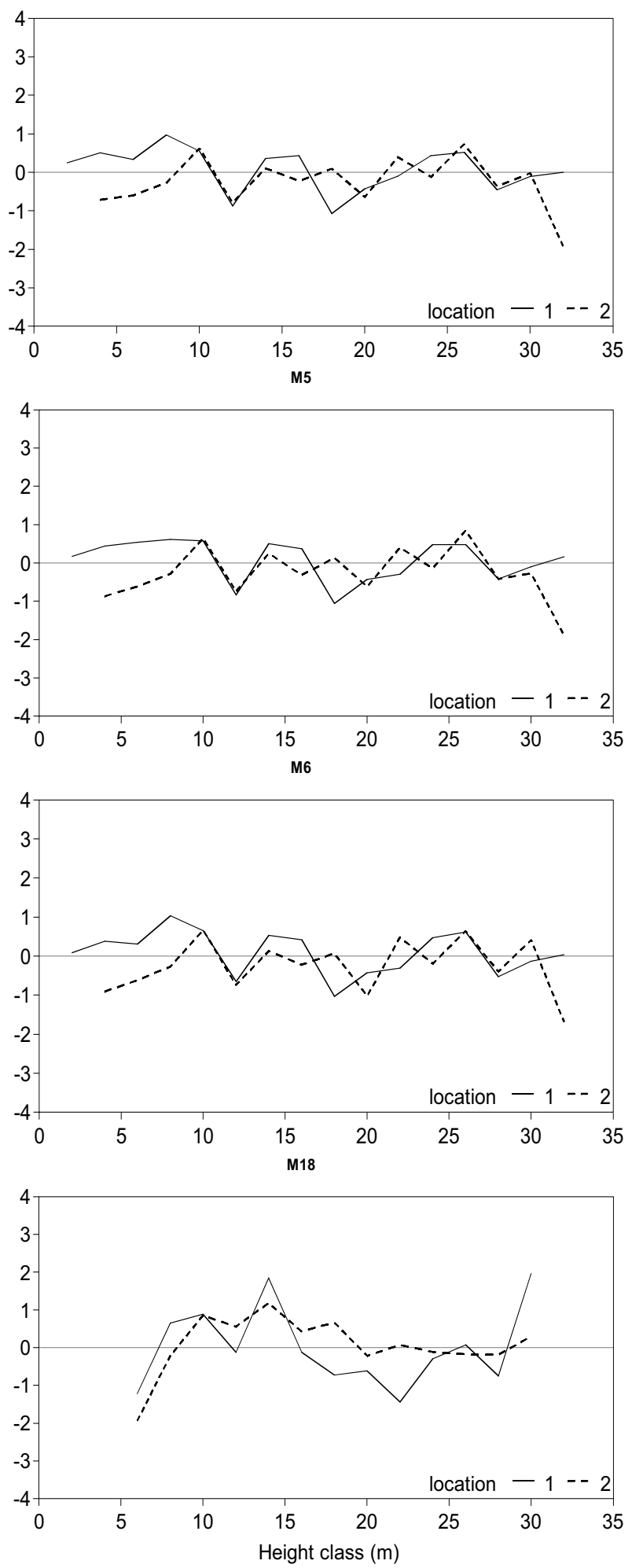

Fig. 2: Mean residuals in dbh class and mean residuals in height class

diameters, competitions) into the height-diameter models (Adame et al., 2008; Crecente-Campo et al., 2010; Dorado et al., 2006; Newton and Amponsah, 2007; Schmidt et al., 2011; Sharma and Parton, 2007; Temesgen and Gadow, 2004).
Each of the promising models (except M9, M17 and M18) showed almost identical prediction behaviors within the observed data range. Because of fewer observations, validation with data-splitting was not considered even though that validation is an important part of modelling 
(Soares et al., 1995; Vanclay and Skovsgaard, 1997). Some of the models might be flexible enough to be used for extrapolation purpose. However, it would be risky to do so without validation and verification. Most reliable way of checking model's prediction behavior beyond the ranges of the calibration data would be to test the fitted models against newly acquired data from different tree populations over a wider ranges of size, site qualities and stand conditions (Kozak and Kozak, 2003; Vanclay, 1994; Vanclay and Skovsgaard, present models are site-specific, they may not necessarily be representative to the same species grown in other sites even within the same district. Prior to the application for Blue pine forests in places other than Lete and Kunjo, testing of this research's models is crucial. Formulation of the same dummy codes as in Eq. (2) is necessary while applying the models. The follow-up research on our models (i.e. recalibration, verification, and validation) with data from the widest possible tree sizes, ages, site qualities and stand conditions of
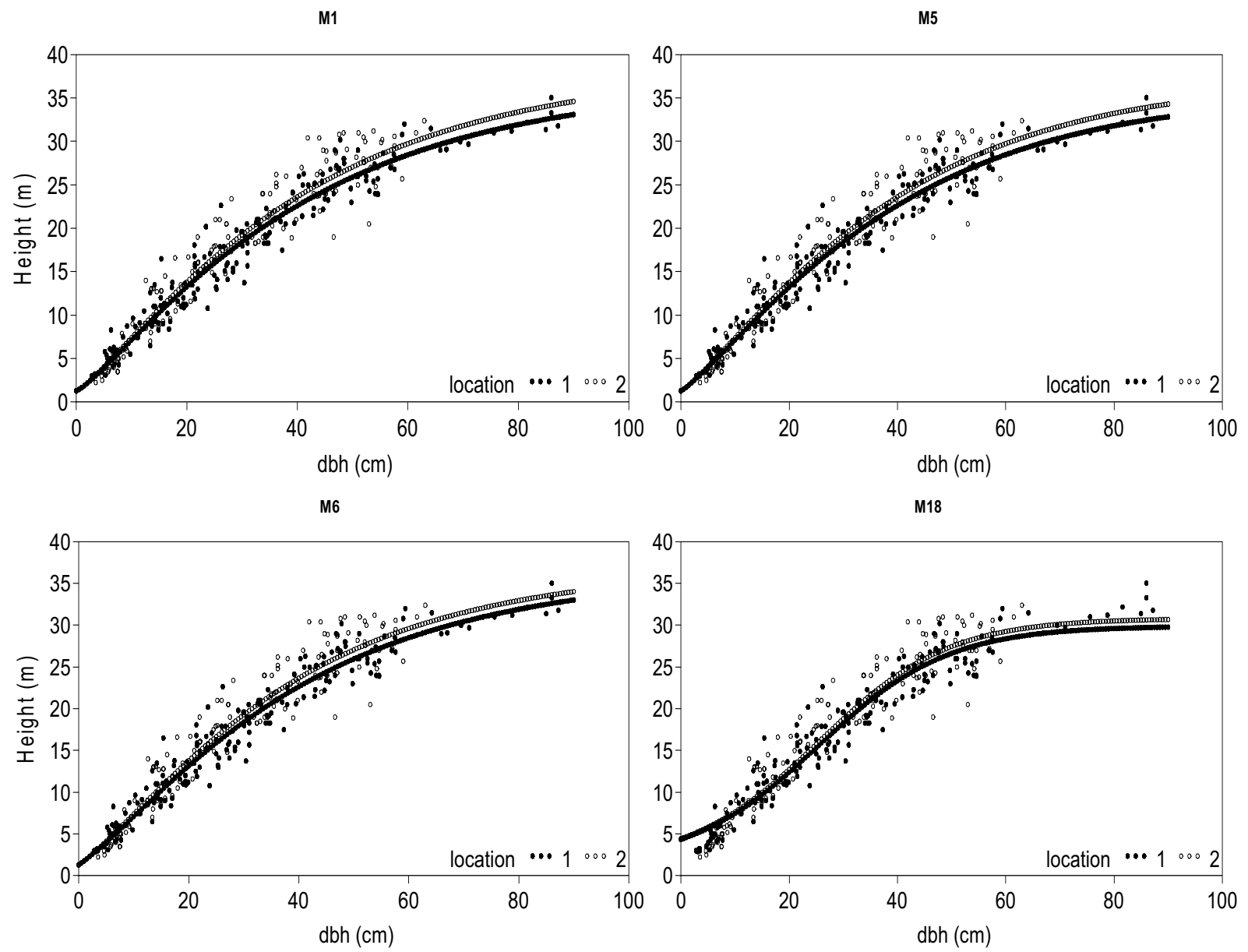

Fig. 3: Model curves overlaid on observed data

1997; Yang et al., 2004). But getting such data, in general, would be very costly, and therefore are rarely attempted.

\section{Conclusions}

Among eighteen models calibrated, Weibull model (M5) showed the best fits (smallest RMSE and AIC, and largest $\mathrm{R}^{2}$ adi) followed by M6, M1, M16, M3 and so on. Weibull model (M5) is recommended for the prediction of total height of Blue pine trees for Lete and Kunjo. Since the
Blue pine forests across Lete and Kunjo forest areas in Mustang district would be useful.

\section{Acknowledgements}

This paper is based on a part of the first author's MSc thesis submitted to Tribhuwan University (TU), Nepal. The Community Based Natural Forest and Tree Management in the Himalaya project (ComForm project) provided financial support to this work. We wish to thank 
Dr Henrik Meilby in Copenhagen University of Life Sciences, Denmark, and both Dr Bimal K. Paudel and Dr Santosh Rayamajhi at the Institute of Forestry, TU, Nepal for their academic supports. We are thankful to those all who supported to field works. We thank the anonymous reviewer for constructive comments on earlier version of the manuscript.

\section{References}

Adame, P., del Rio, M. and Canellas, I. 2008. A mixed nonlinear height-diameter model for pyrenean oak (Quercus pyrenaica Willd.). Forest Ecology and Management 256 (1-2): 88-98.

Alder, D. 1995. Growth modelling for mixed tropical forests. In Tropical Forestry Paper No.30. Nuffield Press, Oxon, 231.

Bates, D. M. and Watts, D. G., 1980. Relative curvature measures of nonlinearity. Journal of Royal Statistical Society 42: 1-16.

Burnham, K. P. and Anderson, D. R. 2002. Model Selection and Multimodel Inference. A Practical Information-theoretic Approach. Springer Science Business Media, Inc, New York, USA.

Calama, R. and Montero, G. 2004. Interregional nonlinear height-diameter model with random coefficients for stone pine in Spain. Canadian Journal of Forest ResearchRevue Canadienne De Recherche Forestiere 34 (1): 150-163.

Cato, S., McMillan, L., Donaldson, L., Richardson, T., Echt, C. and Gardner, R. 2006. Wood formation from the base to the crown in Pinus radiata: Gradients of trachied wall thickness, wood density, radial growth rate and gene expression. Plant Molecular Biology 60: 565-58.

Chhetri, M., Maskey, L. K., Chapagain, N. R. and Sharma, B. D. 2004. Mustang- the Land of Fascination. King Mahendra Trust for Nature Conservation (KMTNC), Nepal.

Crecente-Campo, F., Tomé, M., Soares, P. and Dieguez-Aranda, U. 2010. A generalized nonlinear mixed-effects height- diameter model for Eucalyptus globulus L. in northwestern Spain. Forest Ecology and Management 259 (5): 943-952.

Curtis, R. O. 1967. Height-diameter and heightdiameter-age equations for second growth Douglas fir. Forest Science 13: 365-375.

DFRS. 1999. Forest Resources of Nepal. Department of Forest Research and Survey. Ministry of Forests and Soil Conservation, HMGN/ FINNIDA, Report No.74, Kathmandu, Nepal.

Dorado, F.C., Dieguez-Aranda, U., Anta, M.B., Rodriguez, M. S. and von Gadow, K. 2006. A generalized height-diameter model including random components for radiata pine.plantations in northwestern Spain. Forest Ecology and Management 229 (1-3): 202213.

Fang, Z.X. and Bailey, R.L. 1998. Height-diameter models for tropical forests on Hainan Island in southern China. Forest Ecology and Management 110 (1-3): 315-327.

Gunary, D. 1970. A new adsorption isotherm for phosphate in soil. European Journal of Soil Science 21: 72-77.

Hasenauer, H. and Monserud, R.A. 1997. Biased predictions for tree height increment models developed from smoothed 'data'. Ecological Modelling 98 (1) : 13-22.

Hossfeld, J. W. 1822. Mathematik für Forstmänner. Ókonomen und Cameralisten [in German].

Huang, S., Price, D. and Titus, S.J. 2000. Development of ecoregion-based heightdiameter models for white spruce in boreal forests. Forest Ecology and Management 129:125-141.

Huang, S., Titus, S.J. and Wiens, D.P. 1992. Comparison of non-linear height-diameter functions for major Alberta tree species. Canadian Journal of Forest Research 22: 12971304. 
Huang, S. and Titus, S. J. 1993. An index of site productivity for uneven-aged or mixedspecies stands. Canadian Journal of Forest Research 23: 558-562.

Jackson, J. K., 1994. Manual of afforestation in Nepal. Forest Research and Survey Center. Ministry of Forests and Soil Conservation, Kathmandu, Nepal.

Khanna, L.S. and Chaturbedi, A.N.1994. Forest Mensuration. International Book Distributors, Dehradun, India.

Kozak, A. and Kozak, R. 2003. Does cross validation provide additional information in the evaluation of regression models? Canadian Journal of Forest Research 33 (6): 976-987.

Kyastha, B.P. 1986. Silvics of the Trees of Nepal. Community Forestry Development Project, Kathmandu, Nepal.

Leduc, D. and Goelz, J. 2009. A height-diameter curve for longleaf pine plantations in the gulf coastal plain. Southern Journal of Applied Forestry, 33 (4): 164-170.

Lu, J. F. and Zhang, L. J. 2011. Modeling and Prediction of tree height diameter relationships using spatial autoregressive models. Forest Science 57 (3): 252-264.

Meilby, H., Puri, L., Christensen, M. and Rayamajhi, S. 2006. Planning a system of permanent sample plots for integrated long-term studies of community based forest management. Banko Janakari 16 (2): 3-11.

Meyer, H. A., 1940. A mathematical expression for height curves. Journal of Forestry 38 (5): 415-420.

Montgomery, D.C., Peck, E.A. and Vining, G.G. 2001. Introduction to Linear Regression Analysis. $4^{\text {th }}$ Ed. John Wiley and Sons, New York, USA.

Moore, J.A., Zhang, L. and Stuck, D. 1996. Height-diameter equations for ten tree species in the Inland Northwest. Western J. of Applied Forestry 11: 132-137.
Näslund, M. 1936. Skogsforsö ksastaltens gallringsforsök i tallskog [Thinning experiments in pine forest conducted by the forest experiment station]. Meddelanden fran Statens Skogsforsöksanstalt 29: 1-169 (In Swedish).

Newton, R.F. and Amponsah, I.G. 2007. Comparative evaluation of five heightdiameter models developed for black spruce and jack pine stand-types in terms of goodness-of-fit, lack-of-fit and predictive ability. Forest Ecology and Management 247 (1-3): 149-166.

Nord-Larsen, T. 2006. Developing dynamic site index curves for European beech (Fagus sylvatica L.) in Denmark. Forest Science $\mathbf{5 2}$ (2): 173-181.

Nord-Larsen, T., Meilby, H. and Skovsgaard, J.P. 2009. Site-specific height growth models for six common tree species in Denmark. Scandinavian Journal of Forest Research 24 (3): 194-204.

Peng, C. 2001. Developing and validating nonlinear height-diameter models for major tree species of Ontario's boreal forest. Northern J. of Appliied Forestry 18: 87-94.

Pretzsch, H. 2009. Forest Dynamics, Growth and Yield. Springer Verlag, Berlin, Germany.

Ratkowsky, D. A. 1990. Handbook of Nonlinear Regression Models. Marcel Dekker, Inc. Vol. 107, New York, USA.

Ratkowsky, D. A. and Reedy, T. J. 1986. Choosing near-linear parameters in the four parameter logistic model for radioligand and related essays. Biometrics 42: 575-582.

Richards, F. J., 1959. A flexible growth function for empirical use. Journal of Experimental Botany 10: 290-300.

SAS Institute Inc. 2008. SAS/ETS1 9.1 User's Guide. SAS Institute Inc., Cary, NC 
Schmidt, M., Kiviste, A. and von Gadow, K. 2011. A spatially explicit height-diameter model for Scots pine in Estonia. European J. of Forest Res. 130 (2): 303-315.

Sharma, M. and Parton, J. 2007. Height-diameter equations for boreal tree species in Ontario using a mixed-effects modeling approach. Forest Ecology and Management 249 (3): $187-$ 198.

Sharma, M. and Zhang, S.Y. 2004. Height-diameter models using stand characteristics for Pinus banksiana and Picea mariana. Scandinavian J. of Forest Res. 19 (5): 44 2-451.

Sharma, R.P., 2006. Modelling growing space requirement for Alnus nepalensis $\mathrm{D}$. Don. in Nepal. Banko Janakari 16 (2): 30-36.

Sharma, R.P., 2009. Modelling height-diameter relationship for Chir pine trees. Banko Janakari 19 (2): 3-9.

Sharma, R.P., Brunner, A., Eid, T. and Øyen, B.H. 2011. Modelling dominant height growth from national forest inventory individual tree data with short time series and large age errors. Forest Ecology and Management $\mathbf{2 6 2}$ (12): 2162-2175.

Soares, P., Tomé, M., Skovsgaard, J. P. and Vanclay, J. K. 1995. Evaluating a growth model for forest management using continuous forest inventory data. Forest Ecology and Management 71 (3): 251-265.

Temesgen, H. and Gadow, K.V. 2004. Generalized height-diameter models: an application for major tree species in complex stands of interior British Columbia. European J. of Forest Res. 123: 45-51.

Thornley, J. H. M. 1999. Modelling stem height and diameter growth in plants. Annals of Botany, 84: 195-205.
Trincado, G., Vander Schaaf, C. L. and Burkhart, H.E. 2007. Regional mixed-effects heightdiameter models for loblolly pine (Pinus taeda L.) plantations. European J. of Forest Res. 126 (2): 253-262.

Vanclay, J. K. and Skovsgaard, J.P.1997. Evaluating forest growth models. Ecological Modelling, 98 (1): 1-12.

Vanclay, J. K., 1994. Modelling Forest Growth and Yield. Applications to Mixed Tropical Forests. CAB International, Oxon, UK.

Wagle, B.H. 2007. Growth of Blue pine (Pinus wallichiana) in Lete and Kunjo of Mustang District. MSc Thesis, Tribhuwan University, Institute of Forestry, Pokhara, Nepal

Wagle, B. H. and Sharma, R. P. 2012. Modelling individual tree basal area growth of Blue pine (Pinus wallichiana) for Mustang district in Nepal. Forest Science and Technology (in press).

Weibull, W., 1951. A statistical distribution function of wide applicability. Journal of Applied Mechanics 18: 293 -296.

Yang, Y. Q., Monserud, R. A. and Huang, S. M. 2004. An evaluation of diagnostic tests and their roles in validating forest biometric models. Canadian J. of Forest Res. 34 (3): 619-629.

Zeide, B. 1993. Analysis of growth equations. Forest Science 39 (3): 594 - 616.

Zhang, L.J., Bi, H.Q., Cheng, P. F. and Davis, C. J. 2004. Modeling spatial variation in tree diameter-height relationships. Forest Ecology and Management, 189 (1-3): 317-329. 